\title{
原料豆の貯蔵，浸漬および潅水条件が豆もやしの発芽， 生長におよぼす影響十
}

\author{
田尻尚士* \\ Effect of Conditions of Storage, Soaking and Sprinkling \\ of Seed of Beans on the Sprouting and Growth \\ of the Bean Sprouts
}

TAKASHI TAJIRI

\begin{abstract}
A study was conducted to determine the effects of temperature and period on the qualities of three kinds of beans during storage, and the effects of temperature and time of soaking and sprinkling on the rate of sprouting of the beans in order to make good bean sprouts. The good bean sprouts were produced when seeds of beans were stored under $0^{\circ} \mathrm{C}$ and $85 \% \mathrm{RH}$ for $5-7$ months after picking, and they were soaked in water at $30^{\circ} \mathrm{C}$ for 5 to 7 hours and then sprinkled with water of temperature at $30^{\circ} \mathrm{C}$ for 15 minutes at 4 hours intervals. Under these conditions, germination rate as \% was $80-83 \%$ for soybeans and Adzuki beans, and $90-91 \%$ for mung beans. The length of hypocotyl was $15-17 \mathrm{~cm}$ for soybeans and mung beans, and $7-8 \mathrm{~cm}$ for Adzuki beans. The thikness of hypocotyl was $3.5 \mathrm{~mm}$ for soybeans, $2.7 \mathrm{~mm}$ for mung beans, and $3 \mathrm{~mm}$ for Adzuki beans. In the cases of prolonged storage of seeds of beans at high temperature $\left(10-20^{\circ} \mathrm{C}\right)$ rate of water absorption into the beans was low and percent of germination of the beans was considerably low. When the temperature for soaking was low and the period of soaking was inevitably prolonge sprouting of seed of beans became slow and water absorption of the beans became excessive. Then, these beans tend to decay. When the temperature of sprinkling water was low, the lengthening and thickening of hypocotyls of beans became slow. When sprinkling water was exessive, hypocotyls became dark in color. So, the qualities of the bean sprouts were hard to retain marketable condition.
\end{abstract}

(Received Aug. 9, 1979)

豆類もゃしの需要は增大の一途をたどっている。わか 国では長崎において明治 40 年 ${ }^{11}$ 頃より専門の製造業者 が出現し，種子を浸漬，発芽させ，夏期にのみ栽培する 小規模なものであったと言われているが，明確な文献，

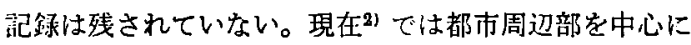
約 1,280 社が存在するが，製造方法，品質管理面にお いて不明な点が多く，茷埰時期，原料豆の品質などが製 品豆もやしの品質を左右し，市場性もきわめて不安定で
ある。

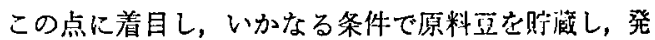
芽，栽培すれば四季を通して平均した良質の豆類むやし が製造されるかにつき，大豆，緑豆，小豆を用いて笑軻 したのでここに報告する。

\section{実 験 方 法}

豆類もやしの製造方法は前報》と同栐に行なった。

$\dagger$ 豆類むやしの型造と鮮度保持性に関する研究（第 2 報）（前報交献 3)) Studies on Production and Keepind Quality of Beans Sprouts (Part 2)

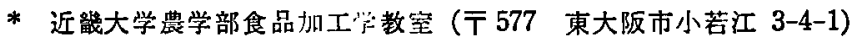

Laboratory of Food process, Faculty of Agriculture, Kinki University.

Kowakae, Higashi-Osaka, Osaka, 577 


\section{1. 材 料}

北海道産大豆袖振（Glycine max Merr)，四国産緑豆 (Vigna radiata, $\mathrm{L}$ )，北海道産小豆 (Vigna angularis レ）を用いた。

\section{2. 原料豆の吸水量}

原料豆を収穕直後より 16 力月間にわたり $0,10,20^{\circ} \mathrm{C}$ -RH 85\%（湿度は常に RH 85\% の一定とした。）恒湿 恒温室に各原料豆を 2,000 粒眝蔵し, 邀時 100 粒を取り 出し浸漬水温 $30^{\circ} \mathrm{C}$ 下で吸水させ, 重量增加より吸水量 を求めた。

\section{3. 発牙率}

2 と同様の処理操作を行なった原料豆各々 1,000 粒を 1 斗梅（桧製）に投入し，電磁形汇より恒温タンクを通 して $20,25,30^{\circ} \mathrm{C}$ の水を 4 時間毎 15 分間潅水し発芽率を 求めた。

\section{4. 豆類もやしの生長度測定}

上述の吸水，発芽率において最良区であった $0^{\circ} \mathrm{C} \cdot \mathrm{RH}$ $85 \circ$ 下で収穫 5 力月間貯蔵の原料豆各々 1,000 粒を用い $\tau, 20,25,30^{\circ} \mathrm{C}$ の 3 潅水区を設定し， 7 日間の栽培を
行い，各豆もやし 100 体につき胚軸の長さ，太さ，生体 重, 胚軕と根部の比率（もやし部全長と胚柚部の長さ） を経洔的に測定した。

\section{実 験 結 果}

\section{1. 原料豆の吸水量}

吸水所要洔間は原料豆の貯蔵温度，期間により左右さ れたが全般的には大豆 $6 \sim 8$, 緑豆 7 8, 小豆 $8 \sim 9$ 時 間を要した。

各原料至とむ漫清水温は $30^{\circ} \mathrm{C} \cdot 5 \sim 7$ 時間処理が豆部 の膨張感，表皮のはりからみて最もよいと思われ，同時 に吸水状能もほぼ゙ークを示した。浸漬時間 10 時間で は原料豆は約 2 倍に膨張し，表皮は破損し 2 分するもの が多く認められ，この結果吸水過度となった。

また，吸水傾向は各豆類ともほほ同㥞相を示すか，浸 漬 1〜7 時間にわたってかなり急速に吸水し，以後きわ めて緩慢な吸水状態を示した。なお，原料豆眝蔵温度に

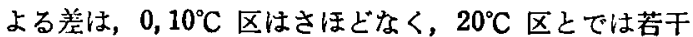
の差を示し，とくに，大豆，小豆区では浸清 1〜5 時間
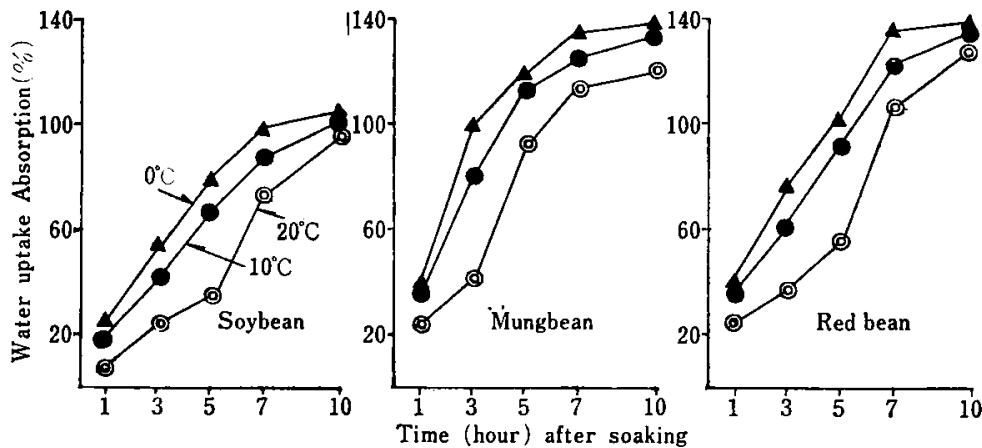

Fig. 1-1 Relation between storage periods and temperatures of (raw material) beans and the time required for the completion (end) of water absorption of the beans

Temperature of soaking water: $30^{\circ} \mathrm{C}$
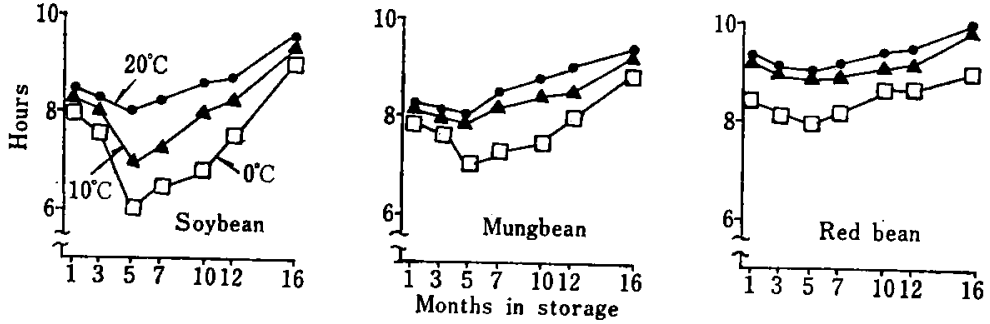

Fig. 1-2 Effect of storage temperatures on water absorption rates of raw material beans Storage period: 5 months

Temperature for soaking: $30^{\circ} \mathrm{C}$ 

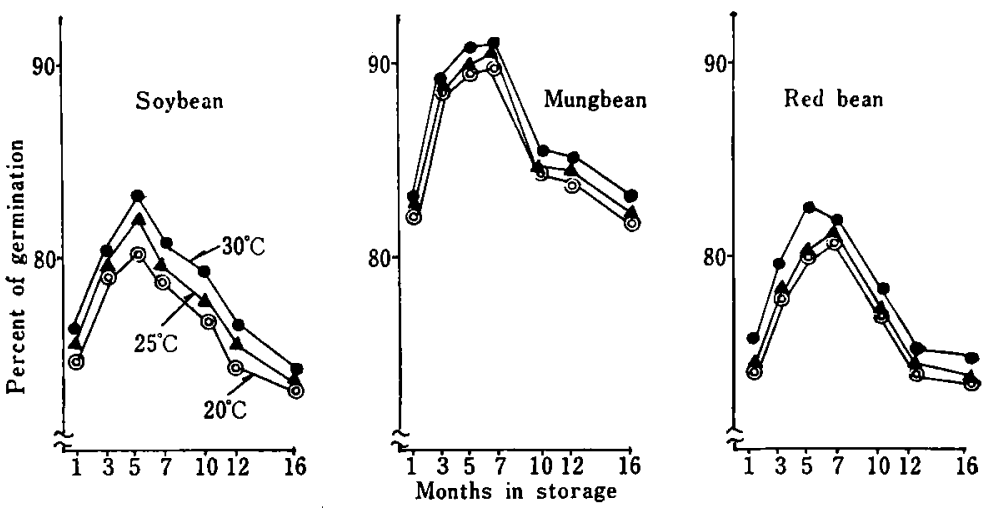

Fig. 2 Effects of the storage period of (raw material) beans and the temperature of sprinkling on the germination of the beans

Storage temperature of beans: $0^{\circ} \mathrm{C}$ Time for soaking: 5 hours
Temperature for soaking: $30^{\circ} \mathrm{C}$

Sprinkling of water: 15 minutes at 4 hours intervals
まで吸水作用は縟慢で以後かなり急速に吸水する傾向が 認められた。大豆は緑豆, 小豆より浸漬直後の吸水量は やや低く, 吸水終了は約 1 時間早い結果を示した。

原料豆の貯藏温度と期間が吸水速度におよぼす影響它 みると，唄蔵温度が高いほど緩慢であり，低い埸合は忽 速であり，短時間で吸水完了する。眝蔵期間により吸水 状態は異り，貯蔵期間分短期（1３ 力月)，長期（12〜 16 力月）では吸水速度は縍慢で，貯藏 $5 \sim 7$ 力月間が最 む吸水作用は活発であった。

この結果，豆類もやしの製造，栽培における原料豆の 浸漬は $30^{\circ} \mathrm{C} \cdot 5 \sim 7$ 時間処理が最適であり，原料豆の貯 藏は $0^{\circ} \mathrm{C}(\mathrm{RH} \mathrm{85 \% )}$ で 5〜7 カ月間が良好であった。 浸漬過度 (吸水過度)となると原料豆は 2 倍強に膨張し, 豆部は 2 分し胚芽部は離脱した。

\section{2. 原料豆の発茅率}

1 の最良区 $\left[0^{\circ} \mathrm{C}(\mathrm{RH} 85 \%) \cdot 5\right.$ 力月貯蔵原料豆を $30^{\circ} \mathrm{C} \cdot 5$ 時間浸漬] の処理を行なった結果, 大豆, 小豆 は類似した発芽率を示した。

各豆類区とも実際の刑造過程でみられる $80 \%$ 弱より やや高い 80〜83\% となり，緑豆では他の豆類より高い 90〜91\%となった。潅水温度別にみれば温度が高いほど その発芽率は高く，30区が最高であり，実際の製造過 程における处理温度と一致した。原料豆の貯蔵温度，期 間別にみれば吸水量と同様 $0^{\circ} \mathrm{C}(\mathrm{RH} 85 \%) \cdot 5$ 力月貯蔵 区が最良の発芽萃となった。大豆，小豆では貯蔵 12〜16 カ月では発芽菜 $75 \%$ 前後となり最艮区より約 $10 \%$ 低下 する。緑豆では 16 力月貯蔵で最良区より低下するが 80 \%前後と高い発牙率を示した。

\section{3. 豆類もやしの生長度}

(1) 肧軸部の肥大生長は Fig. 3-1 に示した。各豆類 もやし区とも栽培 5 日前後が最高值を示し，以後若干細 くなった。潅水温度別では温度が，高いほど肥大生長は 大きく，早い傾向を示し，大豆むやしではこの傾向が影 著であった。大豆もやしは緑豆，小豆もやしょり 0.6 $\mathrm{mm}$ 前後太く, 小豆もやしの肧軸肥大は縁豆, 大豆より も緬慢で栽培 4〜6 日間でほぼ肥大生長は終了した。潅 水温度 $30^{\circ} \mathrm{C}$ と $20^{\circ} \mathrm{C}$ 区では各もやしとも胚軸肥大流 $1.0 \sim 0.5 \mathrm{~mm}$ の小差となった。

(2) 胚軸部伸長度は Fig. 3-2 に示した。伸長度は大 豆, 緑豆もやしでは子葉附着点から根部先端までとし， 小豆はもやしでは子葉附着点から肧軸部先端までとし た。伸長度は栽培日数の增加と正比例して增加，栽培 5 日間で最滈点となり，以後ほぼ伸長は停止する傾向がみ られた。潅水温度 $20,25^{\circ} \mathrm{C}$ では $30^{\circ} \mathrm{C}$ に比して 2 4 日 間伸長度が遅れた。大豆，緑豆もやしに比べ小豆もやし は約 $1 / 2$ の伸長となった。これは小豆もやしが他のもや 乙と異り，胚軸部之根部が同時に別途に出芽，生長する ためであろう。本結果は収䅫後 5 カ月間 $0^{\circ} \mathrm{C} \cdot(\mathrm{RH} 85$ \%）に貯蔵した場合の原料豆を使用したもので，潅水温 度別にみれば，温度が高いほど伸長度は大きく，とくに， $30^{\circ} \mathrm{C}$ と $20^{\circ} \mathrm{C}$ 区では栽培 5 日間で大豆るやし $10.3 \mathrm{~cm}$, 緑豆むやし $10.2 \mathrm{~cm}$, 小豆むやし $3.8 \mathrm{~cm}$ の大差を生し た。前述の胚軸部の肥大生長と反比例し, 伸長度が大と なる時点では肥大生長は低下期となり，ある程度肧軸が 肥大したのち胚軸は伸長期へと移行することが認められ た。 

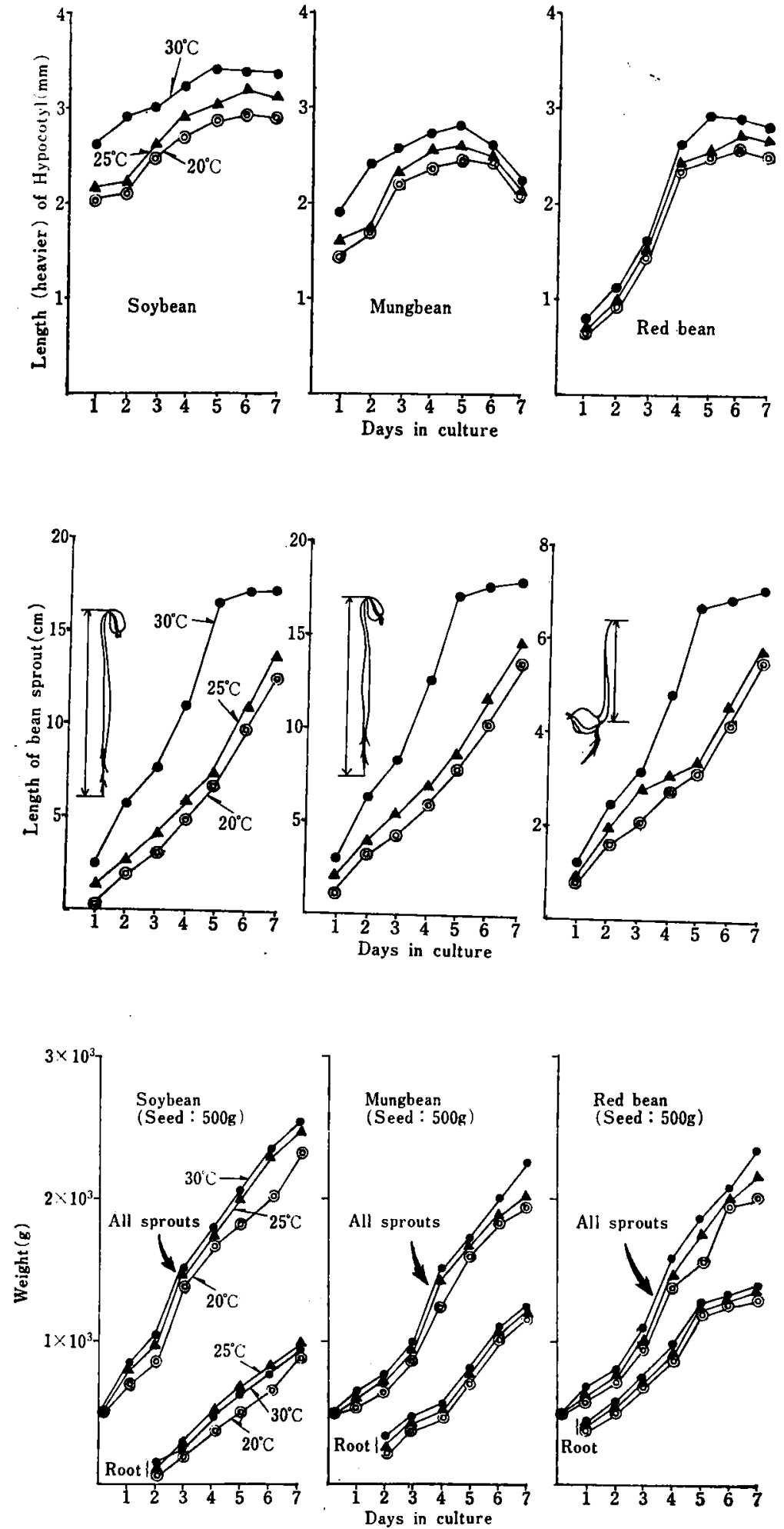

Fig." 3-1 Effect of temperab. ture of sprinkling water on the elongation of hypocotyl of bean sprouts

$$
\begin{aligned}
& \text { Storage temperature of } \\
& \text { beans: } 0^{\circ} \mathrm{C} \\
& \text { Time for soaking: } 5 \text { hours } \\
& \text { Sprinkling of water: } 15 \\
& \text { minutes at } 4 \text { hours inter- } \\
& \text { vals }
\end{aligned}
$$

F!g. 3-2 Effect of the temLi perature of sprinkling I water on the growth of bean sprout

Storage temperature of beans: $0^{\circ} \mathrm{C}$

Time for soaking: 5 hours Sprinkling of water: 15 minutes at 4 hours intervals

Fig. 3-3 Effect pof the temFeratures of sprinkling - water on the weight of bean sprous

\footnotetext{
Storage temperature of beans: $0^{\circ} \mathrm{C}$

Time for seaking: 5 hours

Sprinkling of water: 15 minutes 4 hours intervals
} 


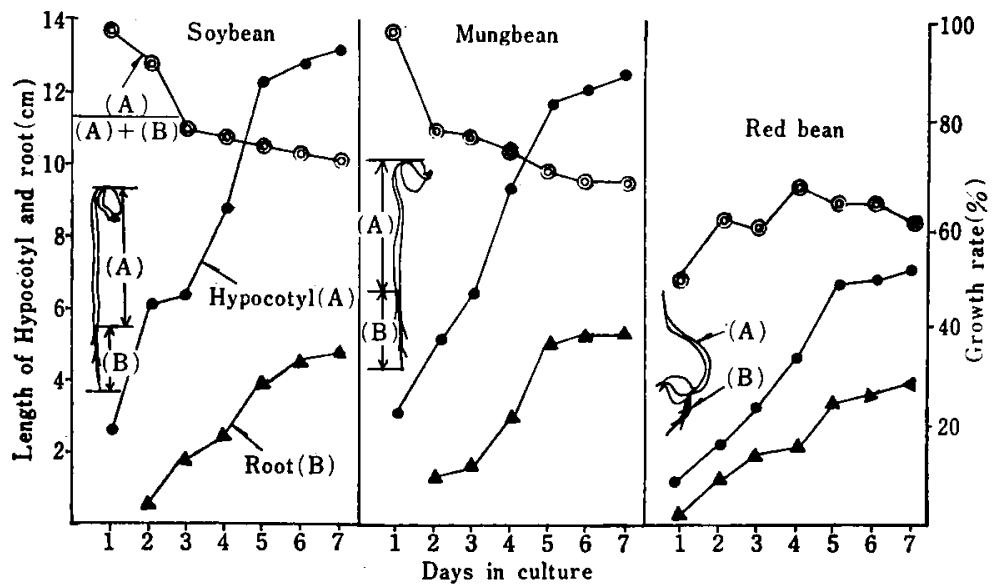

Fig. 3-4 Changes in growth rates of hypocotyls and roots of bean sproufs

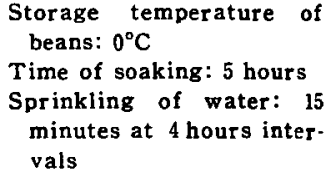

（3）生体重增加は Fig. 3-3 に示した。生体重は栽培 日数の増加と比例增加するが，大豆もやしでは栽培初期 から栽培終了まで平均的に增加し，緑豆，小豆もやして は栽培 2〜3 日間は緩慢で 4～7 日にわたって急增する。 豆むやし全重量は栽培 7 日間で大豆もやし 5 倍強, 緑豆, 小豆もやしでは 4 倍強となった。潅水温度別では，温度 が高いほど生体重增加速度は早く大きく，その格差は栽 培 4〜5 日頃より大となった。全もやし重量中に占める 根部重量比は，大豆もやし $40 \%$ ，緑豆，小豆もやし 55 〜 57\%となり，大豆むやしは栽培初期より終期に至り平 均的な状態を示し，小豆もやしでは栽培初期より終期人 漸次占有率は低下した。緑豆もやしは終始 $55 \%$ 前後を 保持した。

（4）肧軸部々根部の伸長度比率は Fig. 3-4 に示した が，最良生長度を示した潅水温度 $30^{\circ} \mathrm{C}$ 区では，大豆， 緑豆むやしは類似した様相を示し，栽培初期（1～3日） に胚脷部の伸長度が若干高く，以後やや低下するが，小 豆もやしでは根部，胚軸部が別途に発芽生長するため， 栽培 1〜3 日迄は胚軸部と根部の生長はさほど垟がなく， やや胚軸部が少し早い程度であった。全般的に生卧面で の最大期となる栽培 4〜5 日前後では，根部に比べて胚 軸部の仲長度がやや高い傾向が認められた。栽培 5 日前 後より根部に㑡根の発生がみられ，やや黑ずむ橡相がみ られふ。豆類もやしでは栽培 3 日前後まで胚軸部の伸長 がより盛えで以後根部の伸長がみられる。小严もやしの みこの様相と異り，胚軸部，根部は各々栽增初期から中 期へともに伸長することが認められた。

\section{考察}

（1）原料豆の吸水状況
浸漬直後が急激に高くなるがその後経時的に吸水作用 は緩慢となる。各豆類とも浸漬 6〜9 時間で吸水作用は ほぼ終了する。眝蔵温度と吸水作用は，貯蔵中での外公 水煮気(4) と種子含水量との関係により, 本実験での $0 \mathrm{C}$ -RH 85\% では原料豆はやや乾燥状態にあり，その結 果, $30^{\circ} \mathrm{C}$ 浸清での吸水速度は活発で速やかったものと思 われる。原料豆の貯蔵期間と吸水量では, 貯蔵 5〜7カ 月が最良で 1〜3 カ月および 12 16 力月貯蔵では吸水 作用はきわめて縞慢で長㭙間を要した。収種直後では後 熟不充分であり ${ }^{61,6)}$ ，長期貯蔵では種子内組織の乾燥過 度となり睡裂や酵素活性の低下などにより吸水作用は低 下したものと考えられる。

(2) 原料豆の発茅萃

各豆類とも潅水温度が高いほど高率となり，温度によ る差異はかなり顕著であった。 $0^{\circ} \mathrm{C}(\mathrm{RH} 85 \%) \cdot 5$ 力月 貯蔵の原料豆を $30^{\circ} \mathrm{C} \cdot 5$ 時間浸漬し $30^{\circ} \cdot 4$ 時間每 15 分潅水での発芽率は，大豆，小豆で 82 83\%，緑豆 90 $\sim 92 \%$ と高い発芽率を示した。吸水量と比例し，吸水作 用が早く，高いほど発芽率も高い結果を示した。発牙に は初期の吸水量》が重要であり，胚，胚乳は貯蔵中に乾 固状態で生長を一時停止し，浸漬により吸水後種子は休 眠を打破され，発芽に際し活動が活発となることから， $30^{\circ} \mathrm{C}$ 潅水区が最良の結果を示したが，潅水時間について は, 潅水量の多少や長時間連続は水分温多や酸素欠乏な どを誘引し，発芽案恃低下するものと考えられることか ら，4時間毎・15分潅水処理が最適でありと思われる。

(3) 豆類もやしの生長度

胚軸部の肥大生長は，栽培初期か大で潅水温度が高い ほど肥大生長のは速くなる。肥大生長は細胞の增加でな く細胞の肥大によるるのとされており，栽培日数か䅅過 
するにつれ肥大期より分裂期への進行し，次いで栽增中 期（3〜5日）より胚軸部は伸長期へと移行し肧軸部は，心 速に伸長, 細化与る。以後双葉の発生や, 側根発生へと 進展する。この様相は各豆類もやしに共通し，潅水温度 加高いほど伸長度は高く早い。

肧軸部生体重增加は, 各豆類もやしとも枇淮 $3 \sim 7$ 日 へと大きく増加し，以後さほど変化しない。海水温度に よる涪異は非常に小さい。根部の熄加も胚帆部之同傾向 を示すが豆類もやし中に占める根郘重量は栽培日数の增 加とは逆に低下する。これは根部細胞 ${ }^{199}$ の分裂により， 側根などの発生期へ進行するため根部の生理的生長期に 至ることが原因であろう。最良生長を示した大豆，緑豆

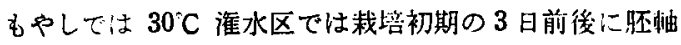
部の伸長率は低下し，以後ほとんど变化なく漸次根蔀の

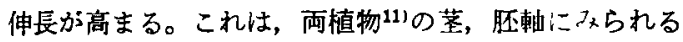
組䋨，形成異が進展し胚軸部は地上，地下部に分裂する ためであろう。

小豆もやしでは, 胚軸部, 根部が別途に発茅生よ゙する がほほ傾向は類似し，栽培 1〜4 日間は胚軸伸長が大き く，以後は低下する。各類もやしとも栽培日数の增加に つれ，組織は充实，発達し細胞分裂や形成層が次第に進 展し根部は若正遅れて充実進行することから胚軸部生長 は一時停止し, 根部の充実, 根毛発生へと移行するもの であろう。

\section{要 約}

豆類もやし製造における原料豆の眝藏と浸溑，潅水の 温度条件などによる発芽，生長につき検剖した。

1. 原料豆の吸水, 発芽は浸清水温, 潅水温度や洔間 に左右される。各原料豆とも浸漬水温 $30^{\circ} \mathrm{C}$ が最適であ り, 収㨨後 5 7 力月貯蔵の原料豆が最高の吸水, 発芽 率を示した。原料豆の貯蔵温度は本研究の範囲内では, $0^{\circ} \mathrm{C} ・(\mathrm{RH} \mathrm{85 \%})$ が最適であった。貯藏温度が们く，浸 清水温が低い場合では吸水速度は幄く，原料豆は軟弱と なり胚軸部の離脱が多発する。吸水要時間は 5〜9時間， 発芽率は大豆，小豆で 82〜83\%，粶豆 90〜91\% となっ た。結果，浸漬，発芽は速やかに行い原料豆組織の破壊 をまねかぬ様処理することが重要である。汶水，吸水が 速やかであれば発芽率も良好で以後の肧軸部の肥大生長 も良好で栽堷操作が良好となる。また，30 $\mathrm{C} ・ 4$ 時間每 15分淮水処理が最適であり，潅水温度は原料豆を㳄化， 凮攻させる原因となった。
2. 豆類もやしの生長度は，楼培初期（1～3日）に胚 䛆部の肥大生長期を示し，次いで胚軸部伸長と根初伸压 となり，漸次根毛発生から朴获登生へと進行するので, 豆類もやし栽培に扒いて初期 1〜3 日間の潅水処理が重 要不久可となる。生体重增加は戒培日数の增加とともに 大となるが, 肧軸部重量は栈上初期より綏慢に低下する。 小豆もやしは大豆，緑豆の上速の栐相と異り，栽涪中期 まで增加し, 以後漸次重量は低下寸る。栽培 7 日以上と なると双葉，根毛沙登生し，豆もやしの市場性は消失す る。

3. 総合的には, 原料至は収㮃後 $5 \sim 7$ 力月間 $0^{\circ} \mathrm{C}$ ・ (RH 85\%) で眝蔵し， $30^{\circ} \mathrm{C} \cdot 5 \sim 7$ 時間浸清し，発芽床 に移し $30^{\circ} \mathrm{C} ・ 4$ 時間等 15 分間潅水它行なえば大豆，小 豆で 80〜83\%，緑豆：90〜91\%の良好な発芽率となり， 以後の栽培もきわめて順衕となる。栽培 5 日前後が市場 性最適のもやしとなり大豆 15〜17 cm, 小豆 7〜8 cm, 緑豆 $15 \sim 17 \mathrm{~cm}$ の長さとなり，胚軸激の太さは，大豆 もやし $3.5 \mathrm{~mm}$, 緑豆もやし $2.7 \mathrm{~mm}$ ，小豆もやし 3.0 $\mathrm{mm}$ となり，良質の豆類もやしが栽培，製造された。

終りにのぞみ本実験の遂行にあたり，有意義な御指導 を頂いた大阪府立大学教授故粕方邦方博士，ならびに㖘 学博士茶珍和雄氏をはじ園菜任品利用学研究室の各位 に深謝いたします。

\section{文献}

1）農林水産省食品流通局野菜振興課：特産野菜ハン ドブック，地球社，p. 450 (1977).

2) 同上: p. 452 .

3）田尻台士：日食工誌 26,18 (1979).

4) Hyde, E.O.C.: Am. Bot. N.S. 18, Plate 2, 240 (1954).

5) 中山勾：農林暂子の発芽，内田老鹤囷新社，42 (1966).

6) 同 上: p. 132 .

7) 古谷雅樹・宮地重速・论村敦彦：生活環の制御 (植物生理学捧座 4), 朝會書店, p. 201 (1972).

8) Doneen, L.D., and MacGilliuray, J.H.: Plant Physiol., 18, 574 (1943).

9）宮崎義光：豆もやしに閏与る赛験的研究，園芸学 研究集録 3, 257 (1946).

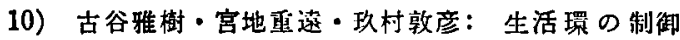
(植物生理学座 4), 胡目書店, p. 61 (1972).

11）同上：物質の交換と輸送（植物生理学貄座 5 ）, 朝倉書店, p. 31 (1972).

（昭和 54 年 8 月 9 日受理） 